\title{
РОЛЬ МЕДИЧНОЇ СЕСТРИ У ПРОФІЛАКТИЦІ МЕТАБОЛІЧНОГО СИНДРОМУ
}

\author{
Шапошнікова В. М., \\ кандидат медичних наук, завідувачка кафедри фахових медичних та фармачевтичних \\ дисииплін Черкаської медичної академії, м. Черкаси, Україна, \\ ORCID ID: https://orcid.org/0000-0002-2161-0612
}

Степанова Г. М., кандидат біологічних наук, старший викладач кафедри фундаментальних дисииплін Черкаської медичної академї̈, м. Черкаси, Україна, ORCID ID: https://orcid.org/0000-0002-2863-3155

Шапоиніков Ю. В., бакалавр медсестринства, Черкаська медична академія, м. Черкаси, Украӥна, ORCID ID: https://orcid.org/0000-0002-0691-903X

DOI: https://doi.org/10.31435/rsglobal_ws/30062020/7114

\section{ARTICLE INFO}

Received: 25 April 2020

Accepted: 10 June 2020

Published: 30 June 2020

\section{KEYWORDS}

metabolic syndrome, type 2 diabetes mellitus, insulin resistance, nurse prophylaxis, treatment, nursing process.

\begin{abstract}
The article reveals the relevance and essence of the metabolic syndrome problem. According to studies, in developed countries 15$25 \%$ of people aged 40-70 years have symptoms of metabolic syndrome. The role of a nurse in the effective prevention and treatment of metabolic syndrome is presented. An improvement in the well-being and quality of life of patients with metabolic syndrome after correction of the patient's lifestyle was noted.
\end{abstract}

Citation: Shaposhnikova V. M., Stepanova H. M., Shaposhnikov Yu. V. (2020) The Role of the Nurse in The Prevention of Metabolic Syndrome. World Science. 6(58), Vol.2. doi: 10.31435/rsglobal_ws/30062020/7114

Copyright: (C) 2020 Shaposhnikova V. M., Stepanova H. M., Shaposhnikov Yu. V. This is an openaccess article distributed under the terms of the Creative Commons Attribution License (CC BY). The use, distribution or reproduction in other forums is permitted, provided the original author(s) or licensor are credited and that the original publication in this journal is cited, in accordance with accepted academic practice. No use, distribution or reproduction is permitted which does not comply with these terms.

Актуальність. На початку третього тисячоліття перше місце серед усіх причин захворюваності та смертності людини посідають серцево-судинні захворювання (СС3). Значну роль у цьому відіграла зміна способу життя, пов'язана із гіподинамією, надмірним харчуванням, хронічними стресами. Зростання кількості хворих із ССЗ спричинили фактори ризику (ФР), які виникли внаслідок розвитку цивілізації [1; 3]. Наприкінці XX століття взаємозалежне поєднання ФР почали називати терміном «метаболічний синдром» (МетС) [2; 4; 14].

Заснував сучасну концепцію МетС американський вчений Джеральд Рівен (Gerald Reaven) у 1988 p. Він встановив головний чинник виникнення МетC - інсулінорезистентність (IP) [5]. На сьогодні МетC - це одне із основних проблемних питань в галузі охорони здоров'я багатьох країн світу. Частота МетС серед населення $є$ високою. Раніше МетС вважався хворобою людей старшого віку, проте, на сьогодні збільшився відсоток осіб молодого віку, які мають цей патологічний стан.

Кластери метаболічного синдрому створюють надзвичайно високий ризик розвитку атеросклерозу, ішемічної хвороби серця (IXC), цукрового діабету (ЦД) та його судинних ускладнень [6; 7]. Отже, принцип виділення паталогічного стану «метаболічний синдром» полягає у концепції виявлення групи пацієнтів із високим ризиком розвитку кардіологічної та ендокринної патології. 
Отже, МетС, як інтегрована проблема медицини, потребує удосконалення процесу профілактики, діагностики, лікування, догляду за пацієнтами, у тому числі й медсестринського.

Ця робота присвячена аналізу проявів МетС серед дорослого населення на прикладі міста Черкаси (Україна) та спрямована на розширення форм профілактики МетС серед населення.

\section{Матеріали і методи.}

Дослідження було проведено впродовж 2019 р. на базі поліклінік та амбулаторій первинного рівня надання медичної допомоги міста Черкаси. Мета дослідження: вивчити поширеність МетС та його складових, обгрунтувати заходи профілактики та визначити роль медичної сестри у їх реалізації.

Вивчили показники МетС населення міста; виявляли ознаки МетС серед кагорти пацієнтів міської поліклініки $(n=500)$, у тому числі чоловіків $(n=250)$ та жінок $(n=250)$, віком 30-69 років. Пацієнти були поділені на групи: із нормальною масою тіла; надлишковою; 3 ожирінням I ст. та II-III ст. Кожна група розподілена на підгрупи за віком та статтю: 30-39, 4049, 50-59, 60-69 років. Досліджували доцільність застосування елементів профілактичного медсестринського догляду.

Об'єкт дослідження випадки МетС серед дорослого населення м. Черкаси. Формування та перебіг ускладнень соматичної патології у хворих з проявами МетС. Предмет дослідження: частота МетС, кластери МетС (абдомінальне ожиріння (АО), ЦД 2-го типу, артеріальна гіпертензія (АГ), інсулінорезістентність (IP), низький рівень холестерин ліпопротеїдів високої щільності (ХС ЛПВЩ).

Для вирішення завдань та досягнення мети були застосовані відповідні методи: аналітичний огляд джерел інформації, епідеміологічні, антропометричні. Проведено скринінг на МетC та визначали IMT. Програма обстеження включала: збір анамнезу, огляд пацієнтів, оцінка скарг пацієнтів, вивчення амбулаторних карток. Інструментальні методи: вимірювання артеріального тиску, антропометрію, яка включала визначення зросту, маси тіла, IMT; визначення АО (ОТ, ОС, ОТ/ОС). Лабораторне дослідження: біохімічне обстеження крові у пацієнтів 3 вісцеральним ожирінням: загальний холестерин (ХC), холестеринліпопротеїдів низької щільності (ХС ЛПНЩ), холестерин ліпопротеїдів високої щільності (ХС ЛПВЩ), тригліцеридів та рівень глюкози натще. Проводили анкетування з визначенням психологічного стану та особливостей харчової поведінки, що призводить до формування ожиріння.

Наявність надлишкової маси тіла та ожиріння визначали за IMT (індекс Кетле) [42] згідно критеріїв ВООЗ (2016), за формулою 1:

$$
\mathrm{IMT}=\text { маса тіла } / \text { ріст }^{2}\left(\kappa г / \mathrm{M}^{2}\right)
$$

Абдомінальний тип ожиріння діагностували за отриманим показником ОТ. Пацієнти були розподілені в залежності від АО визначеного за критеріями Свропейського товариства кардіологів ESC (2012) та Американської асоціації серця АНА (2013) [8; 11]. Верифікація діагнозів ГХ, ЦД та іншої патології серцево-судинної чи ендокринної систем здійснювалися лікарями відділень поліклініки згідно МКХ-10. Дослідження психологічного стану та харчової поведінки пацієнтів проводили за допомогою анкетування. Визначали харчову мотивацію [16], зокрема: нормальну та підвищену.

\section{Результати.}

Проаналізувавши кластери МетС (надмірна маса тіла та абдомінальний тип ожиріння, ДЛП, АГ, IP) та врахувавши гендерну складову виявили, що у чоловіків різних вікових груп зафіксовані розбіжності у ІМТ. На рис. 1. показано розподілення маси тіла чоловіків різного віку.

Поширеність ожиріння III ст. серед чоловіків у віковій категорії 30-39 років не зареєстровано у зв'язку 3 відсутністю таких пацієнтів серед обстежених. У цілому спостерігалась тенденція до збільшення відсотку респондентів з надлишковою масою тіла та ожирінням із віком обстежуваних чоловіків.

Аналіз маси тіла жінок різного віку також показав тенденцію до зростання маси тіла із збільшенням віку жінки (рис. 2.). 


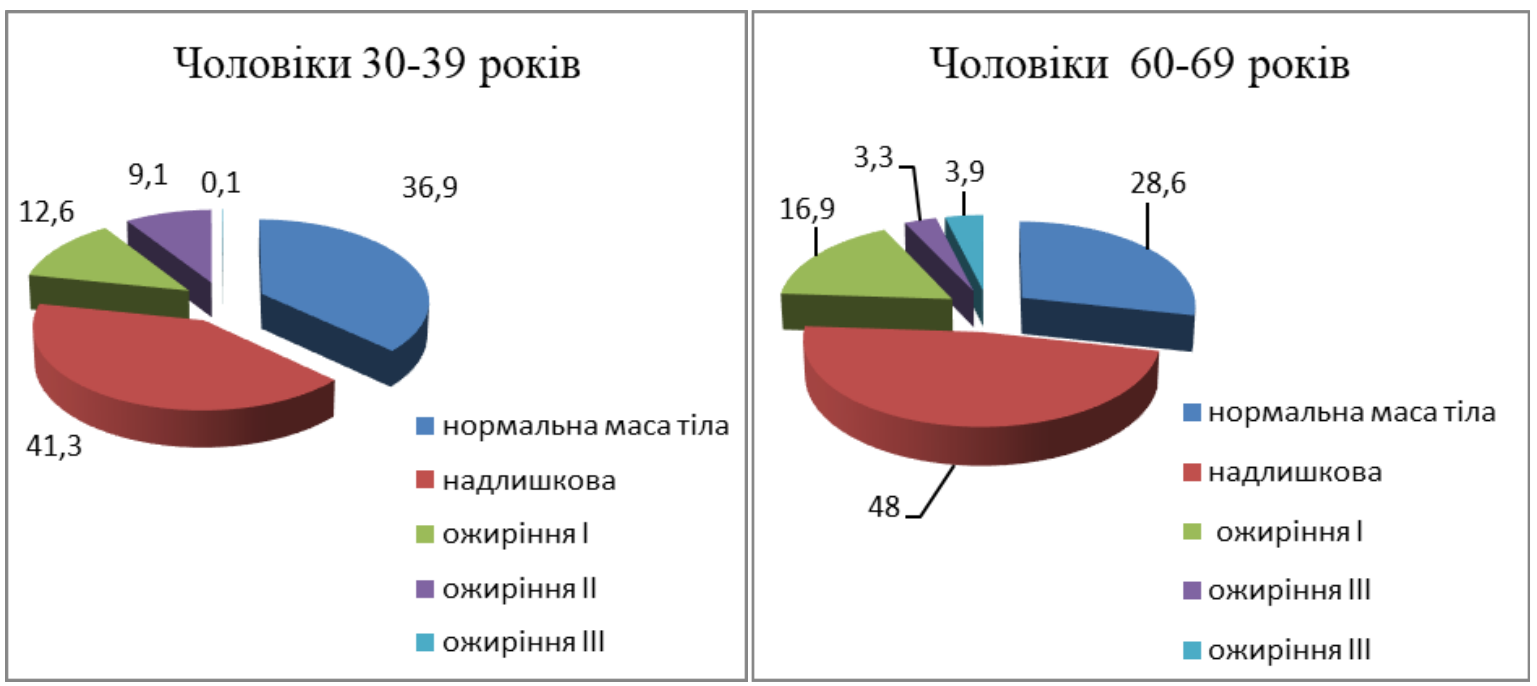

Рис. 1. Розподілення маси тіла чоловіків 30-39 та 60-69 років

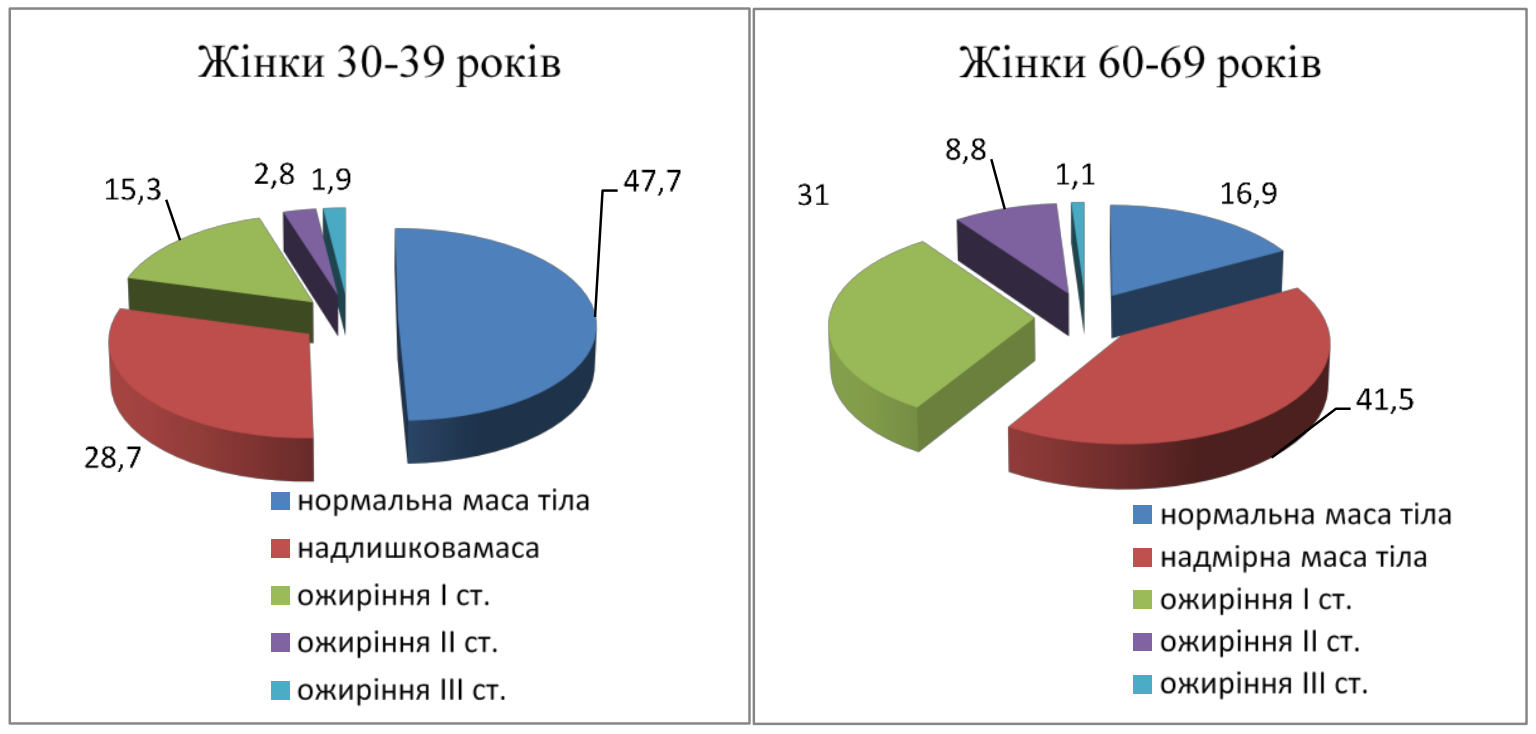

Рис. 2. Розподілення маси тіла жінок віком 30-39 та 60-69 років

Встановлена тенденція до збільшення відсотку осіб із надлишковою масою тіла та ожирінням із зростанням віку обстежуваних жінок.

Виявлено тенденцію до збільшення IMT із віком, як серед чоловіків, так і серед жінок. За даними статистики підтверджено даний факт і серед дорослого населення України в цілому. Все вищенаведе свідчить про кореляцію між віком та зростанням IMT (критерій МетС).

Проведено аналіз наявності соматичної патології, а саме АГ у чоловіків із різним IMT та віком. Враховували спадкову схильність до АГ та анамнез пацієнта. Серед усіх пацієнтів АГ виявлена у 40,7 \% обстежених, за гендерним розподілом у 42,6\% чоловіків та $38,7 \%$ жінок представлено на рис. 3.

Результати показали гендерну складову у розподілі такого критерію МС як маса тіла, зокрема показників захворюваності на АГ. Як видно із рис. 3. розповсюдженість АГ збільшується із віком, проте у пацієнтів з ознаками $\mathrm{MC}$ спостерігається стійка тенденція до зростання розповсюдження АГ серед чоловіків.

Результати лабораторної діагностики крові пацієнтів свідчать, що у віковій групі 30-39 р. гіперхолестеринемія виявлена у 41,2\% пацієнтів; у віці 40-49 р. - складає 47,8\% випадків; у 50-59 р. - 50\% осіб, у 60-69 р. - понад $50 \%$ пацієнтів (рис. 4.). 


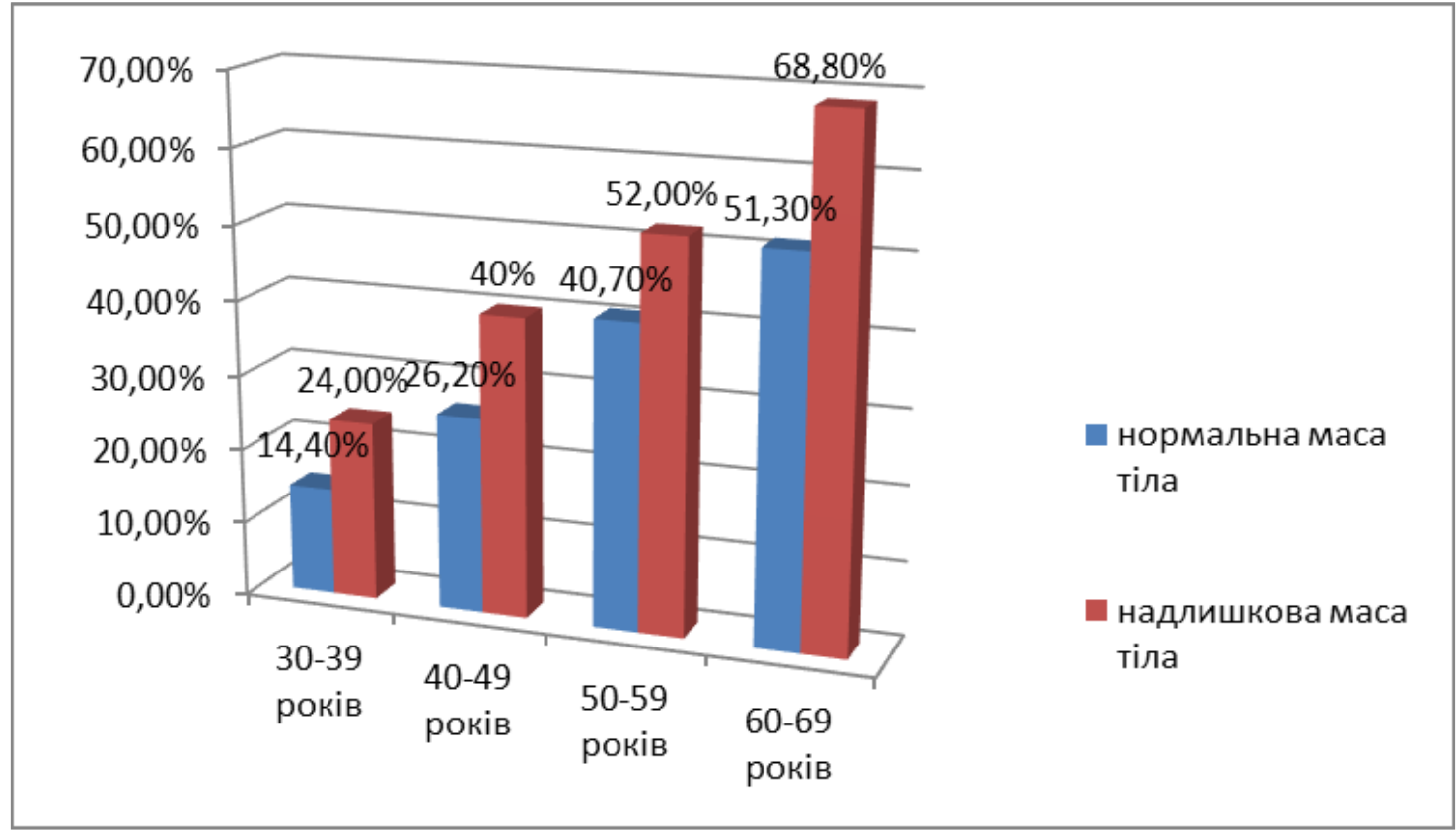

Рис. 3 Розповсюдження АГ серед пацієнтів різного віку та маси тіла

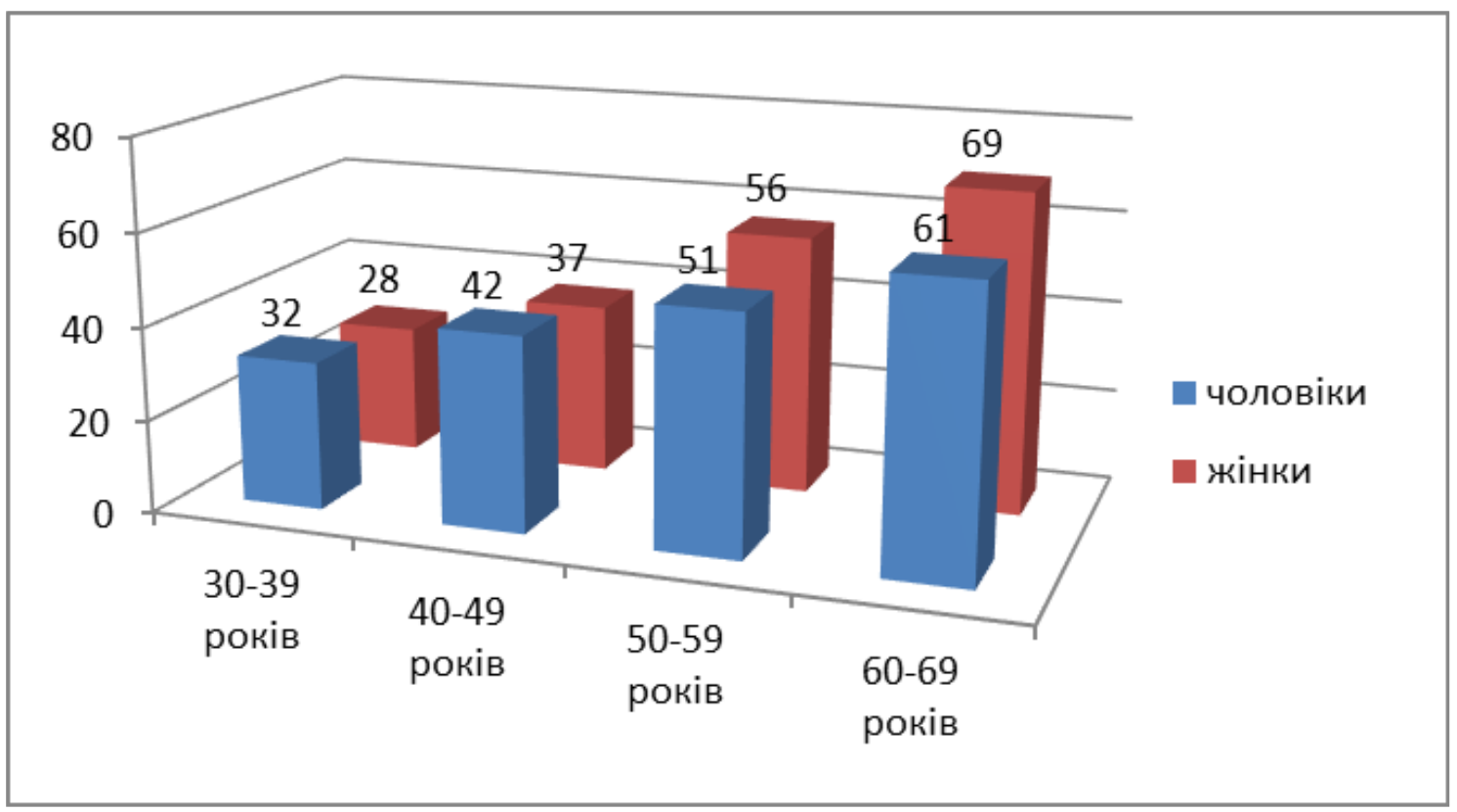

Рис. 4. Гендерний розподіл гіперхолестеринемії

Таким чином, у осіб з нормальною масою тіла відсоток гіперхолестеринемії збільшувався із віком обстежених та був вищим серед жінок віком понад 55 років, у порівнянні 3 чоловіками. Отже, для пацієнтів чоловічої та жіночої статі характерно збільшення гіпертригліцеридемії (критерій МетС) із віком. Тобто контроль за рівнем ліпідів крові $\epsilon$ суттєвим фактором контролю МетС.

Про наявність абдомінального ожиріння та IP у залежності від зростання маси тіла свідчать дані, що у жінок з об’ємом талії (ОT) < 80cм, IP зафіксована у $(22,5 \%$ ), з ОТ > 80см IP - у 47,1 \%; з ОТ < 88 см, ІР виявлена $41,8 \%$, з ОТ > $88 \mathrm{~cm}, 50,4 \%$.

У чоловіків при ОТ $<94 \mathrm{~cm}$, IP виявлена у 14,2\%; при ОТ $>94$ см 39,6 \%; при ОТ $<102$ см IP виявлена у 50,4 \%; при ОT > 102см, IP у 57,5\%. 


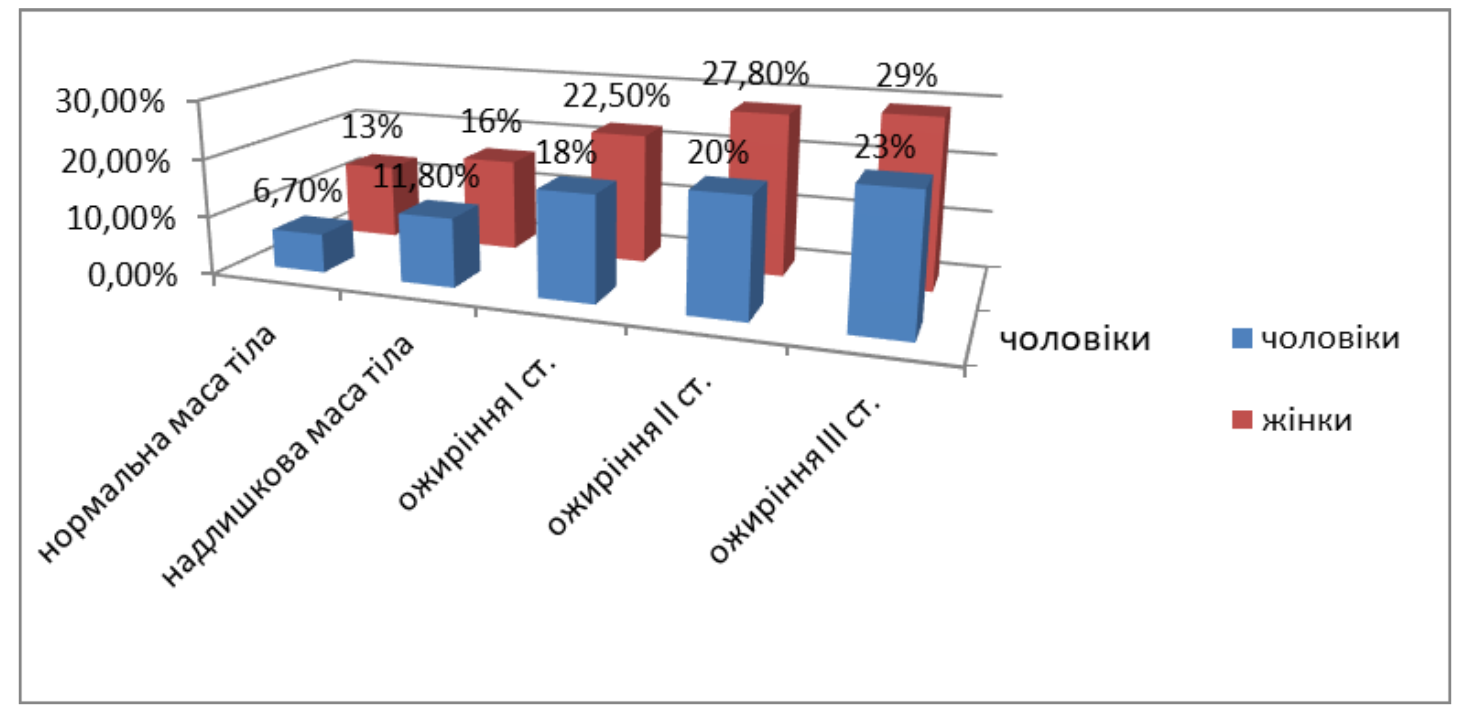

Рис. 5. Поширення IP з урахуванням IMT та віку пацієнтів

Виявлено, що із збільшенням маси тіла та з віком збільшувався відсоток виявлення IP, яка проявляється абдомінальним ожирінням та порушеннями вуглеводного обміну, про що свідчать показники рівня глюкози крові пацієнтів.

Результати виявлення ЦД 2-го типу показали, що діагноз ЦД 2-го типу підтверджено у 2,7 \%. 3 урахуванням гендерної складової, у чоловіків $-2,5 \%$, у жінок $-2,9 \%$ (рис.6.).

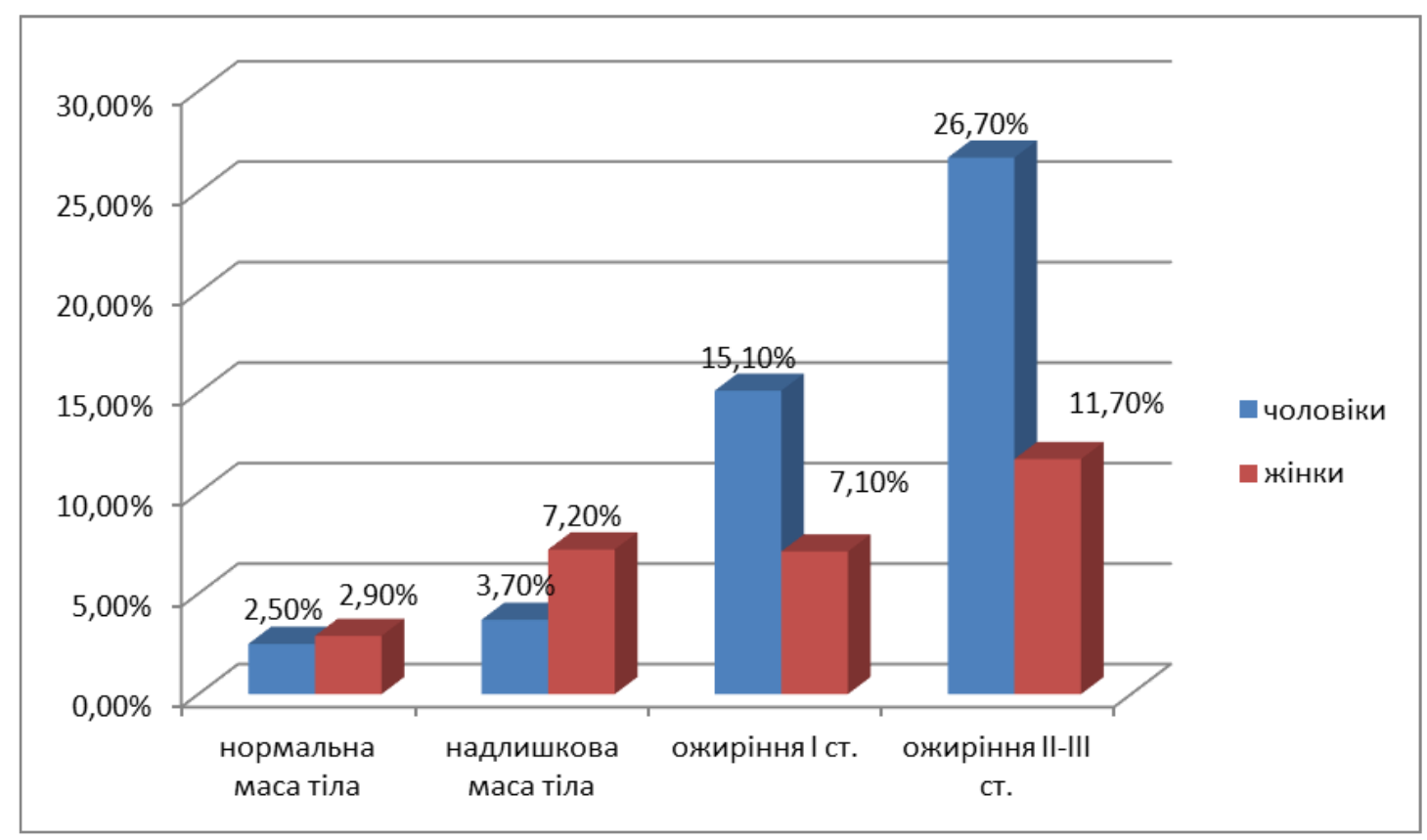

Рис. 6. Поширеність ЦД 2-го типу залежно від маси тіла

Встановлена тенденція зростання поширеності ЦД 2-го типу залежно від маси тіла у чоловіків та жінок.

Проаналізувавши статистичні показники за 2019 р. по місту Черкаси пацієнтів визначили, що МетС зустрічається, в середньому, у 25,7\% населення, це становить $26 \%$ - серед чоловіків та 24,4\% - серед жінок. У осіб середнього віку поширеність МетС серед осіб чоловічої та жіночої статі не має достовірних відмінностей. Серед осіб похилого віку МетС більш поширений серед жінок понад 30 \%, що пов'язано із періодом постменопаузи. Аналіз ретроспективного порівняння показників, за нашими даними, показав тенденцію до зростання показників поширеності МетС та потребує консолідації зусиль медиків, зокрема: сімейного лікаря та медичної сестри, ендокринолога, кардіолога, та, за потреби, хірурга, навколо даної 
інтегральної проблеми медицини. За даними ВОО3, щорічно тільки в Європі реєструють понад мільйон смертей, пов'язаних 3 надлишковою масою тіла, ожирінням i зумовленими метаболічними порушеннями. Саме тому МС визнано однією 3 найважливіших медикосоціальних проблем сьогодення: поширеність МетС висока [9], наслідки важкі, тому ВООЗ визнала його пандемією, що вимагає об'єднання зусиль медичних фахівців різних рівнів для розробки нових підходів профілактики МетС.

Базуючись на результатах дослідження, першим завданням, що стоїть перед медиками щодо профілактики появи МетС, є вчасно розпочате навчання пацієнта здоровому способу життя. Ключова роль у попередженні МетС належить медичній сестрі, яка велику кількість часу приділяє індивідуальній роботі з пацієнтом, визначає його проблеми та планує заходи щодо їх усунення.

Принципові підходи, які може пропонувати пацієнтові сучасна медична сестра, дозволяють позитивно вплинути на прогноз щодо МетС:

1. Санітарна освіта пацієнта, що забезпечує навчання пацієнта медичною сестрою та дозволить поліпшити контроль метаболізму та рівня АТ [10].

2. Немедикаментозна терапія, яка пов’язана 3 корекцією способу життя, достатня фізична активність, що поліпшує метаболічний контроль.

3. Нормалізація харчової поведінки пацієнта.

4. Навчання самоспостереженню пацієнта за станом власного здоров'я, контроль маси тіла.

5. Контроль рівня АТ, глюкози крові, ліпідограми.

6. Регулярний медичний огляд.

Усі ці рекомендації мають високий рівень доказовості, перевірений на численних дослідженнях, клас рекомендацій - I, рівень доказовості - А $[11 ; 12]$.

Майже дві третини пацієнтів відмічали схильність до переїдання та порушення харчової поведінки. Пацієнта слід попередити, що при різкому обмеженні калорій, на фоні суворих дієт виникає психологічна депресивна реакція пацієнта. Цей стан може змінитися на період посиленого вживання їжі та різкого набору надлишкової маси тіла. Таким чином, МетС $є$ результатом саме нераціональної харчової поведінки.

Медсестринські втручання відіграють значну роль при веденні пацієнта із МетС. Доцільно запровадити школу медсестринського навчання модифікації способу життя серед пацієнтів первинної ланки. У роботі якої ми вважаємо за необхідне проведення медичною сестрою наступних заходів:

1. Харчування спрямоване на зниження маси тіла та нормалізацію метаболічних порушень. Пацієнту необхідно пояснити, що вагу потрібно знижувати поступово. Вуглеводи повинні бути використаними: не менше як 400 г овочів та фруктів. Жири не повинні складати більше $30 \%$ раціону, із них $1 / 3$ тваринного походження, а $2 / 3$ - рослинні жири. В дієту необхідно включати достатню кількість дієтичного білку. Дієтотерапія повинна передбачати зниження споживання загального калоражу. Слід збалансувати раціон так, щоб він містив основні компоненти: протеіни - $15 \%$, ліпіди $<30 \%$, вуглеводи $-55-60 \%$.

2. Другим напрямком роботи по усуненню наслідків МетС є підвищення фізичної активності. Пацієнти, що страждають на МетС, повинні підтримувати достатню фізичну активність для зниження ризику розвитку серцево-судинних ускладнень. Фізичні навантаження повинні бути регулярними, відповідати можливостям організму пацієнта. Показана некваплива ходьба, плавання, велосипедні прогулянки. При цьому слід уважно проводити контроль стану пацієнта, перевіряти показники пульсу, АТ, частоту дихання.

3. Медичній сестрі слід пояснити пацієнтові, що на етапі зниження маси тіла фізичні вправи доповнюють дієту i створюють негативний енергетичний баланс. За сценарію застосування навантажень помірної інтенсивності, відбувається покращення чутливості організму пацієнта до інсуліну, знижується рівень ХС ЛПНЩ, підвихується ХС ЛПВЩ.

$\mathrm{y}$ подальшому потрібна підтримка досягнутої маси тіла, а тут допоможе фізична активність, яка є чинником збереження досягнутої ваги.

Перед початком занять необхідно оцінити чутливість пацієнта до фізичного навантаження за допомогою ряду методів, зокрема, велоергометрії. Інтенсивність фізичного навантаження під час тренувань слід контролювати шляхом визначення частоти серцевих скорочень, досягнутої в ході виконання вправ. 
В залежності від цього показника інтенсивність навантаження може бути низькою (30$50 \%$ ЧСС), помірною (50-70\% ЧСС), інтенсивною (>70\% ЧСС). Пацієнтам, які вели неактивний спосіб життя слід починати з нетривалого (10-15 хвилин) навантаження низької інтенсивності (ходьба) з поступовим збільшенням іiі інтенсивності і тривалості до 40-60 хвилин в день, бажано, щоденні, але не менше 3 разів на тиждень фізичні навантаження, загальною тривалістю не менше 150 хвилин на тиждень. Необхідно пам'ятати, що пацієнтам з АГ протипоказані статичні силові навантаження, що збільшують ризик розвитку ускладнень [13].

4. Необхідна рутинна корекція рівня ліпідів у сиворотці крові. Пацієнтам з вираженою дисліпідемією, що не піддається корекції дієтотерапією, лікар повинен призначати статини, а медична сестра контролювати прийом пацієнтом цих препаратів. Підвищений рівень ХС ЛПНЩ і знижений рівень ХС ЛПВЩ є важливими ФР у хворих на МетС.

5. Психологічна корекція харчової поведінки пацієнта. Майже у двох третин пацієнтів відмічали помірну схильність до переїдання та порушення харчової поведінки. Проте, слід відмітити, що при ожирінні майже у $27 \%$ випадків пацієнти вважали, що у них не має патологічних змін харчової поведінки, а $є$ нормальні звички у харчуванні. Це означає, що у обстежених пацієнтів спостерігалася неадекватна оцінка власної харчової поведінки.

Отже, надзвичайно важливою є роль медичної сестри у роз'ясненні пацієнтові принципів нормальної харчової поведінки та анатомо-фізіологічних особливостей організму. Дослідження останніх років [14; 7] свідчать про порушення у психічній сфері пацієнта при ожирінні, які впливають на формування патологічного харчового стереотипу і прогресу МетС та пов'язаних із ним захворювань. Задача медичної сестри навчити пацієнта правилам нормальної харчової поведінки, культурі споживання їжі, дотриманню режиму приймання їжі, стилю харчування, враховуючи культурні, соціальні, регірійні, етнічні фактори.

Пацієнта необхідно переконати, що порушення харчової поведінки $є$ одним із домінуючих факторів у становленні й розвитку МетС. Особливості харчової поведінки не тільки відіграють важливу роль у підтримці життєдіяльності організму, але можуть бути пусковими факторами формування патологічних типів харчової поведінки, які нерідко приводять до розвитку абдомінального ожиріння, що є одним з основних компонентів МетС.

Порушення типів харчової поведінки пов’язане із серотонінергічною недостатністю [15]. Серотонін - важливий компонент формування патологічних типів харчової поведінки. В організмі відзначаються сезонний біоритм у вмісті серотоніна. Серотонін впливає на нервову діяльність, викликає скорочення гладкої мускулатури кишківника, матки, бронхів, а також звуження судин. В основі реакції організму на серотонін лежать центральні, міотропні, гангліонарні, рефлекторні ефекти. Так, дефіцит серотоніна може призвести до негативних наслідків: підвищення апетиту, алкоголізму, тютюнокурінню, наркоманії, токсикоманії, депресії [5].

Таким чином, пацієнтові слід пояснити, що у розвитку АО провідну роль відіграє харчова поведінка. Регуляція апетиту являє собою складний багатокомпонентний механізм, одним 3 найважливіших ланок якого $є$ реципрокна взаємодія центру насичення й центру голоду, що розташовуються в гіпоталамусі. Проведені ряд досліджень $[7 ; 14$, що свідчать про те, що сигнал про насичення запускає складні реакції гіпоталамо-гіпофизарної та лімбічної систем, частина 3 яких пов'язана 3 позитивними емоціями. За А.М. Вейном, існує тісний взаємозв'язок психічних, емоційних і вегетативних процесів, що лежать в основі адаптації організму до різних подразників зовнішнього й внутрішнього середовища. У ситуації вироблених сімейних стереотипів культу їжі, при нестачі позитивних емоцій, людина може використовувати приймання їжі як компенсаторного способу нормалізації емоційного фону. Переїдання стає джерелом позитивних емоцій [16].

При анкетуванні пацієнтів із надлишковою масою, були виявлені депресивні стани, причому депресія виявлена у $24,7 \%$ пацієнтів. Тобто, при надлишковій масі тіла спостерігається деприсивний стан, що спричиняє емоціогенне переїдання. Отже, результати досліджень психоемоційного стану і якості життя у пацієнтів з МетС дають змогу зробити висновок, що для ожиріння характерним $є$ порушення харчової поведінки - переїдання, причому відзначається неадекватність оцінки своїх дієтичних уподобань, зміна особистісного сприйняття норми при оцінюванні кількості вживаної їжі. Таким чином, порушення психологічного процесу контролю за вагою базується на переважанні «емоціогенного переїдання», що підтверджувалося даними анкетування пацієнтів. 
Висновки. Дослідження показало, що метаболічний синдром - одна 3 найбільш актуальних проблем сучасної медицини, яка має тенденцію до значного поширення серед населення. Виявлено, що поширеність МетС (на прикладі Черкас) у середньому становить $25,7 \%$ населення середнього віку, серед осіб чоловічої та жіночої статі не виявлено достовірних відмінностей (26\% та 24,4\% відповідно). У осіб похилого віку МС більш поширений серед жінок, ніж серед чоловіків. Динаміка показників поширеності МС свідчить про тенденцію до його зростанняа його профілактика $\epsilon$ інтегральним завданням системи охорони здоров'я усіх країн світу. В результаті дослідження було встанослено

1. Медсестринські втручання відіграють важливу роль у веденні пацієнта з МетС інтегрованою командою медичних фахівців.

2. Медичним сестрам первинної ланки доцільно проводити раннє виявлення та формування груп пацієнтів із МетС, серед осіб із потенційно високим серцево-судинним та ендокринним ризиком.

3. Для осіб із МетС рекомендувати участь в роботі «Школи сприяння здоров’ю» у вигляді проведення різних форм медсестринського навчання пацієнтів по модифікації способу життя.

Отже, медикам, зокрема медичним сестрам, необхідно проводити профілактику МетС, як серед здорових пацієнтів, так і серед пацієнтів із надлишковою масою тіла. Питання МетС потребує подальшого дослідження та вивчення.

\section{REFERENCES}

1. Alexandrov, O.V., Alekhina, P.M., Grigoriev, S.P. (2016). Metabolic syndrome. R. Medical Journal. 6: 505. [in Rus.].

2. Alisheva, E.K. (2012). Methods of early diagnosis of insulin resistance / Arterial hypertension. - V. 8, № 1. - P. 29-34. [in Rus.].

3. Belyaeva, O.D. (2011). Metabolic syndrome in patients with abdominal obesity: clinical and molecular genetic aspects [dissertation]. Saint-Petersburg. -377 p. [in Rus.].

4. Metabolic syndrome https://ru.wikipedia.org/wiki/ Metabolic syndrome.

5. Mikhailovskaya, N.S. (2015). Clinical features of coronary heart disease in women in the postmenopausal period, depending on the degree of violation of bone mineral density / Actual nutrition of pharmaceutical and medical science and practice. - No. 2 (18). - S. 62-67. [in Rus.].

6. Mitchenko, O.I. (2011). Diagnosis and prevention of metabolic syndrome, cerebral diabetes, prediabetes and cardiopulmonary arrest: recommendations of Ukrainian cardiologists in Ukraine and Ukrainian cardiologists / Sertsevo-sudinnni zhvoryvuvannya: recommendations for diagnosis, prophylaxis and prevention / as amended. V.M. Kovalenka, M.I. Looty. - K .: Morion. - S. 68-79. [in Ukr.].

7. Mitchenko, O.I. (2004). Pathogenetic bases of metabolic syndrome/ O.I. Mitchenko // New Medicine: Metabolic Syndrome, № 3 (14). - P. 20-24. [in Ukr.].

8. Koval, S.M, Snigurskaya, I.O., Volchenko, G.V. (2004). Antihypertensive therapy for metabolic syndrome/ New Medicine: Metabolic Syndrome, № 3 (14). - P. 25-27. [in Ukr.].

9. Mitchenko EI Metabolic syndrome, diabetes mellitus and cardiovascular diseases / E.I. Mitchenko // Ukrainian Journal of Cardiology. - №5. - 2007. - P. 74-80. [in Ukr.].

10. Mitchenko, E.I. (2009). The relevance of the metabolic syndrome in the prevention of acute cardiovascular events: exaggeration of risk or underestimation of the obvious? / Ukrainian Journal of Cardiology. - № 9. P.56-68. [in Ukr.].

11. Mitchenko OI (2004) Pathogenetic basis of metabolic syndrome. New Medicine, № 4: 20-24. [in Ukr.].

12. Shirt, M.I., Bondarenko, O.O. (2018). Metabolic syndrome: a long path of evolution - from complete denial to a global definition of the problem. Achievements of clinical and experimental medicine, Vol. 3.: https://doi.org/10.11603/1811-2471.2018.v0.i3.8987 [in Ukr.].

13. World Helth Organization (WHO), available at: http://www.euro.who.int/en/healthtopics/noncommunicable-diseases/obesity.

14. Hashemipour, S., Esmailzadehha, N., Hamid H., Oveisi, S., Yakhchaliha, P., Ziaee, A. (2015). Association of metabolic syndrome components with insulin resistance in normal weight population: the Qazvin Metabolic Diseases study. J Endocrinol Invest; 38:1111-5. [in Eng.].

15. Badoud, F., Lam, K.P., Perreault, M., Zulyniak, M.A., (2015). Metabolomics reveals metabolically healthy and unhealthy obese individuals differ in their response to a caloric challenge. PLoS One; 10:e0134613. 373. [in Eng.].

16. Grundy. S., Cleeman, J., Daniels, S. (2015). Diagnosis and Management of the Metabolic Syndrome American Heart Association/National Heart, Lung, and Blood Institute Scientific Statement. Circulation.112:2735-52. [in Eng.]. 